\title{
The Global Democracy Community Gathers in Ulaanbaatar
}

\author{
"The Ministerial promises to become a landmark event for the Community"
}

$$
\text { D. G ansukh(M ongolia) }
$$

The dates of the Ulaanbaatar Ministerial Meeting of the Community of Democracies (CD), which Mongolia has chaired for the last two years, are fast approaching. Mongolia is preparing to host hundreds of guests including diplomats, parliamentarians, youth, women, civil society as well as corporate representatives. Among the dignitaries will be the Royal Thai Prime Minister Yingluck Shinawatra, the Vice Presidents of Nigeria and Costa Rica, Baroness Katherin Ashton of the European Union, four Deputy Prime Ministers, and some forty ministers and deputy ministers, as well as Nobel Peace laureates Aung

There was a time when Aung San Suu Kyi would send her video statement to the conference. This time in Ulaanbaatar, she will address the community in person. San Suu Kyi of Myanmar, and Tawakkol Karman of Yemen. The Ministerial will be the largest gathering of its kind in Mongolian diplomatic history.

\section{Mongolia in the Community of Democracies}

Mongolia, a "small but thriving and increasingly prosperous democracy"1 was among the one hundred six nations who adopted the Warsaw Declaration in 2000 to establish the Community of Democracies. Since then, Mongolia has been an active partner in this growing international coalition of democratic countries committed to support democratic transition and consolidate democratic principles, norms and values. CD becomes a venue where democratic countries, old and new, learn from each other by sharing achievements as well as lessons. The Community is indeed a growing entity with 150 democratic nations invited to the Ulaanbaatar Ministerial.

Mongolia has been serving as part of the Governing body of the Community since 2005. In the past, as a member of the Convening Group of 17 countries, and now as a member of the Governing Council, Troika and Executive Committee.

\footnotetext{
1 http://www.brookings.edu/research/reports/2011/07/08-lithuania-piccone
} 
Mongolia, along with Poland, established and co-chaired the CD Working Group on Education for Democracy. Mongolia also participates in the CD Working groups such as civil society, LEND, and regional cooperation.

\section{Education for Democracy, The Mongolian Presidency's Top Priority - A Key to Long Term Success}

As Mongolia assumed the Chair of the Community of Democracies, it has selected Education for Democracy as our top priority. Our thinking is that people educated in the culture of peace and democracy, in tolerance, and respect for different civilizations and religions, in values of freedom and human rights, are the leading citizens of a democratic society. Education for democracy is essential to protect, consolidate and advance the democratic gains in all societies, especially for those in transition.

The very concept of Education for Democracy was articulated in the Warsaw Declaration of the Community of Democracies back in 2000, and has since reaffirmed this in the successive Ministerial meetings. Mongolia thought it was time to take action in the area of education for democracy.

Therefore, we have launched a number of activities and projects to promote the vital importance of education for democracy, development and prosperity, for finding the right solution of pressing societal issues, and for peace and security in the world.

These include a joint MongoliaCanada project to develop a curriculum framework of education for democracy. The outcome of the project was presented at the Asia-Pacific Regional Conference on Education for democracy held in February 2013, in New Delhi hosted by the Government of India.

\section{Some highlights}

- Established an Initiative Group on Education for Democracy (IGED) in New York on 21 September 2011 consisting of Presidents of Finland, Mongolia, Nigeria and Romania and Prime Minister of Luxembourg.

- 2011 UN Democracy Caucus Meeting was organized under the theme of "Education for Democracy".

- International Seminar on Education for Democracy organized in Ulaanbaatar on 21-22 May 2012.

- The United Nations organized the 2012 International Day of Democracy on the theme of Education for Democracy.

Through Mongolia's efforts, and 50 member countries co-sponsoring, the United Nations General Assembly unanimously adopted in November 2012, a resolution on Education for Democracy for the first time in its history. 
The resolution recognizes that education is key to the strengthening of democratic institutions, the realization of human rights and the achievement of all international development goals, development of human potential, poverty alleviation and the fostering of greater understanding among peoples.

It strongly encourages Member States to integrate education for democracy, along with civic education and human rights education, into national education standards and to develop and strengthen national and sub-national programs, curricula and curricular and extracurricular educational activities.

As the UN Secretary-General, Ban Ki-moon noted, "it is needed so that all citizens in all nations, in democracies young and old, established or fragile, fully understand their rights and responsibilities. And it is especially needed in countries that have made recent democratic gains".

Education for democracy will remain one of the important activities of Mongolia's foreign policy and educational reforms within our own society. As US Secretary of State, John Kerry underlined in his letter to Foreign Minister L. Bold, it "will be an enduring legacy of Mongolia's commitment to democratic values. We have also been very encouraged by Mongolia's efforts to promote democracy in education", he noted.

\section{APID - an Initiative - Key to Strengthening Regional Cooperation}

The Community of Democracies already has a Working Group on Regional Cooperation when Mongolia assumed the Presidency. Mongolia's choice to make strengthening regional cooperation in the Asian region came very much in line with the purpose of this WG. The WG, reinvigorated during the Lithuanian Presidency of the Community of Democracies, continues to enhance regional and cross-regional cooperation for the promotion of democracy by sharing best practices and experience in democratization and the consolidation of democracy. The Republic of Korea and Romania co-chair this Working Group.

Therefore, the President of Mongolia, Tsakhia Elbegdorj and the then President of the Republic of Korea, Lee Myung-bak, agreed to launch the Asian Partnership Initiative for Democracy (APID) to advance and strengthen democracy in the region. This initiative was received positively by President Susilo Bambang Yudhoyono of Indonesia during his State visit to Mongolia in 2012. Mongolia regularly participates in the annual meeting of the Bali Democracy Forum (BDF), an inter-governmental forum for promoting democracy in our region, initiated by Indonesia.

The concept paper distributed to the Asian Foreign Ministers for their initial Meeting during the upcoming Ministerial of the Community of Democracies underlines the functioning of this Initiative as "APID should function as a 
forum of the Asian democracies within the CD therefore, the initial activities of APID should be focused on strengthening democracy in the Asian region".

The Asia-Pacific Foreign Ministers Meeting to be held on the $28^{\text {th }}$ of April, 2013 in Mongolia, will be joined by Afghanistan, Bangladesh, Bhutan, India, Indonesia, Japan, Kyrgyzstan, Myanmar, Nepal, the Philippines, the Republic of Korea, Thailand, Timor Leste, the USA and Canada.

President Ts. Elbegdorj: "Mongolia has nothing to teach but may have something to share"

Exchange of experiences in democracy promotion is another area that Mongolia attaches importance to during its CD Chairmanship. Mongolia's transition to democracy was peaceful and our country is considered to be successful in strengthening democracy and creating democratic society. The UN General Secretary Ban Ki-moon stressed in his message to the $50^{\text {th }}$ anniversary of Mongolia's membership in the UN that, "Mongolia has been at the forefront of promoting democracy as evidenced by its current role of leadership in the Community of Democracies".

Engagement and Strengthening of the Civil Society: Civil society organizations play a central role in the Community of Democracies' activities. Dr. Tomicah Tillman, a senior advisor to the US Secretary of State once said that “... one of the CD's greatest strengths is its ability to provide a framework for collaboration between government and civil society". Canada, chair of the CD WG on enabling and protecting civil society organizations, named Mongolia as a model country for promoting NGO. Establishing an Asian CSO networking will be discussed during the Ulaanbaatar Ministerial.

Mongolia's struggle against corruption is being revitalized during its CD Presidency to consolidate the MDG 9 on developing a zero tolerance environment to corruption in all spheres of society.

\section{Institutional Reforms - Key to The Community's Strength}

The Mongolian Presidency was tasked to accomplish the institutional reforms of the Community of Democracies initiated under the Lithuanian Presidency. As the CD Vilnius Ministerial Conference in 2011 directed, the Chair of the Community has concentrated its efforts on carrying out the reform measures approved by the Ministers.

The first Governing Council of Community with 25 members was established in September 2011 in NY during the UNGA gathering. Then the Governing Council appointed the 8 member Executive Committee in November 2011 in Washington DC.

The appointment of the first Secretary-General and countries' efforts to strengthen the Warsaw based CD Permanent Secretariat were the part of the reform agenda. The signing of the Host Country Agreement with Poland in Ulaanbaatar, 
International Women's Leadership Forum in Ulaanbaatar, 9-10 July 2012: Distinguished women from around the world gathered to discuss the importance of women's leadership in democratic societies.

\section{International Workshop on Election} Related Challenges in Young Democracies in Ulaanbaatar, 8-10 October 2012: A joint undertaking with the International Institute for Democracy and Electoral Assistance. Representatives from 17 countries of Asia and the Arab world shared and learned experiences on a range of topics key to the integrity of electoral processes.

The Community of Democracies has established, upon Mongolia's initiative, an Ad hoc Group to support Myanmar's transition. Mongolia as the Chair of the Group.

April 2012: A two-week training for young Afghan diplomats in Ulaanbaatar. A joint exercise with OSCE.

The Government of Mongolia set up an International Cooperation Fund to further extend our experience sharing with the countries in transition. led the Polish Government to guarantee a status of international organization to the Permanent Secretariat. It has now become a common practice that $\mathrm{GC}$ and $\mathrm{EC}$ meets regularly.

Now the Community has a Geneva based Democracy Caucus that was established in March 2012 in addition to the NY based one.

"Mongolia has done great work in advancing the reforms that we began last year in Vilnius, reshaping the community from a group that highlights democratic ideals, to one that provides concrete support to emerging democracies."

Having successfully accomplished such reforms, the Presidency is working to substantiate the CD's work to make it a dynamic, inclusive and engaging organization. 